\title{
Does Ethical Leadership Really Act as a Positive Role in Sustainable Supply Chain Management?
}

\author{
Syed Abdul Rehman Khan \\ School of Economics and Management, \\ Tsinghua University \\ Beijing, China \\ Sarehman_cscp@yahoo.com \\ Zhang $\mathrm{Yu}$ \\ School of Economics and Management, \\ Chang'an University \\ Xi'an, China
}

\author{
Chen Jian \\ School of Economics and Management, \\ Tsinghua University \\ Beijing, China
}

Hêriş Golpîra

Department of Industrial Engineering, Sanadaj Branch, Islamic Azad University

Sanandaj, Iran

\begin{abstract}
This research explores the role of Ethical leadership, green trainings, green supplier selection and green manufacturing in Sustainable supply chain. A sample of 367 firms' data was collected from Indian manufacturing industry and used structural equation modeling technique to evaluate rese arch hypothesis. The findings revealed that ethical leadership plays a significant role in adopting sustainable supply chain through different determinants including green trainings provided to employees, environmental friendly supplier selection and green manufacturing. Therefore, it is recommended that firms' leadership should act ethically for successful implementation of green practices in business operations.
\end{abstract}

Keywords-Ethical leadership; Green manufacturing; Green supplier selection; Sustainable supply chain.

\section{INTRODUCTION}

Sustainable supply chain plays a vital role in the green economic and environmental sustainability [1]. The term "Sustainable supply chain", "Green supply chain", "Environmental friendly supply chain" and "pro-environmental supply chain" have been used interchangeably in published scientific research papers. In fact, the key objective of green supply chain is to improve environmental beauty without compromising firm financial performance and build competitive edge [2]. Undeniably, after industrialization era, environmental pollution, climate change and global warming become a biggest challenge for governmental authority to mitigate. Sustainable supply chain improve the firms' economic health with better image and reputation, while sustainable/green supply chain builds an pollution free environment and reduces the carbon emissions and waste through different green techniques including, usage of renewable energy in production and logistical operations. In addition, ecological design of products, recycling and remanufacturing techniques significantly mitigate the waste problems with better environmental sustainability [3]. A number of researchers have conducted their researches to find the linkage between green practices, ethical leadership and sustainable supply chain [4-8]. They all found mix and inconclusive results that ethical leadership and internal environmental management with green information system may support and motivate firms to adopt green supply chain practices, but according to the some researchers ethical leadership has no effect on firms so as to adopt green practices including, ecological design of products, green packing and packaging, green marketing and distribution, reverse logistics, usage of renewable energy/biofuels in transportation and logistical operations, green procurement, green supplier selection, green warehousing, green production, remanufacturing and recycling techniques etc. In addition, these green practices also improve firms' financial, environmental, societal and operational performance. Furthermore, green practices also reduce the cost of products and provide export opportunities.

The inconclusive results are a strong motivation to conduct a research to fulfill the gap. For this purpose, the research will help to investigate the link between ethical leadership, green supplier selection, green manufacturing, green trainings to employees and sustainable supply chain from the perspective of Indian manufacturing industry. The article is structured as follows. Section 1 provides introduction and objective of this research. Section 2 covers the literature review and hypothesis formulation. Section 3 contains source of data and research methodology. Section 4 and 5 includes results and discussion, and conclusion respectively.

\section{LITERATURE REVIEW AND HYPOTHESIS}

According to [9], firms are pressurized by governmental authority, NGOs (Non-governmental organizations) and customers to adopt sustainable supply chain for better environmental beauty and to mitigate air and water pollution. On the other hand, numbers of researchers claimed that polluted firms are a significant contributor in different human, fauna and flora diseases including, asthma, heart attack, lungs cancer, hair loss and kidney problems [4, 6]. Firms need to adopt green practices in their supply chain operations so as to maximize the resource utilization and mitigate the harmful 
effects of business activities. Corporate sector introduces green-design innovations due to pressure of governmental authorities and customers demand.

Khan and Dong, [6] conducted an empirical study on green supply chain management to identify the key determinants and they found that governmental bodies and customers are the main determinants of green supply chain, who create pressure on companies to mitigate their harmful effects on society and environmental sustainability. Bansal, [10] argued that some green practices are not positively correlated with financial goals, but several enterprises adopt them due to strict environmental laws and regulations. Prajogo et al. [11] highlighted those ecological practices in business operations significantly improve the performance of firms and create competitive edge in the long run. Biofuels and green technology enhance environmental sustainability and also mitigate carbon footprint, [12], while usage of fossil fuel in logistical and business operations increase the cost of firms. [4, 7] conducted an empirical study on Indian automobile industry to evaluate the impact of critical factors for adopting green practices towards sustainability. The findings revealed that green practice in supply chain (green design, green purchasing, green production, green management, green marketing, green logistics) generate significant contribution to firms' economic, operational, social and environmental performance.

As the environmental awareness is increasing across the globe, firms are facing pressure increasingly to mitigate emissions and waste throughout the supply chain. In last couple of years, evolving, regulatory, financial and competitive pressures, increasing demands from customers and complicated environmental regulations have escalated the attentions towards sustainable supply chain as well as reverse logistics activities. Firms without green capabilities are unable to generate any value towards green supply chain. Banerjee, [13] Hart, [14] highlighted that green practices in strategic planning will improve firm's financial and operational performance and provide opportunity to build competitive edge. Ethical leadership and internal environmental management improve the manufacturing practices and convert polluted processes into green and sustainable supply chain. Ecological design in products enhances environmental and financail performance of firms with better corporate image. Khan et al. [4]; S. Mitra and P.P. Datta, [9] ethical leadership provides green trainings to employees and changes the direction of firms towards sustainable supply chain. Therefore, we suggest the following hypothesis:

H1: Ethical leadership provides green trainings to employees

H2: Green trainings to employees improves and builds sustainable supply chain

H3: Ethical leadership selects suppliers on the basis of their green practices

H4: Green supplier selection has positive effect and promotes green manufacturing
H5: Green manufacturing enhances sustainable supply chain management

H6: Ethical leadership lead towards sustainable supply chain management

TABLE I. PROFILE OF COMPANIES

\begin{tabular}{|c|c|c|c|}
\hline Demographics & Frequency & \multicolumn{2}{|c|}{$\%$} \\
\hline \multicolumn{4}{|l|}{ Respondent Designation } \\
\hline Supply chain directors & & 14 & 3.8 \\
\hline General manager supply chain & & 19 & 5.2 \\
\hline Procurement officers & & 39 & 10.6 \\
\hline Manufacturing head & & 49 & 13.4 \\
\hline Manufacturing engineer & & 37 & 10.1 \\
\hline Warehouse managers & & 42 & 11.4 \\
\hline Product quality analyst & & 64 & 17.4 \\
\hline Supply chain planner & & 77 & 21.0 \\
\hline Logistics manager & & 26 & 7.1 \\
\hline \multicolumn{4}{|l|}{ Industry category } \\
\hline Chemical manufacturers & & 61 & 16.6 \\
\hline Electrical product manufacturers & & 47 & 12.8 \\
\hline Frozen food manufacturers & & 26 & 7.1 \\
\hline Pharmaceutical manufacturers & & 41 & 11.2 \\
\hline Tobacco manufacturers & & 7 & 1.9 \\
\hline Rubber manufacturers & & 87 & 23.7 \\
\hline Iron and metal products manufacturers & & 19 & 5.2 \\
\hline Paper and plastic manufacturers & & 79 & 21.5 \\
\hline
\end{tabular}

\section{Methodology}

This article employed SEM (structural equation modeling) to test hypothesis. After analyzing the content validity of questionnaire, the final questionnaire was sent to 488 manufacturing firms in India, while 367 filled questionnaires were received and total response rate was $75 \%$. There were totally 26 items in questionnaire related to 5 constructs such as Ethical leadership (EL), Green trainings to employees (GTE), Green supplier selection (GSS), Green manufacturing (GM), and sustainable supply chain (SSC). The AMOS software has been used to run structural equation modeling. The research model and firm profile have been drawn in Figure 1 and Table 1 respectively. 


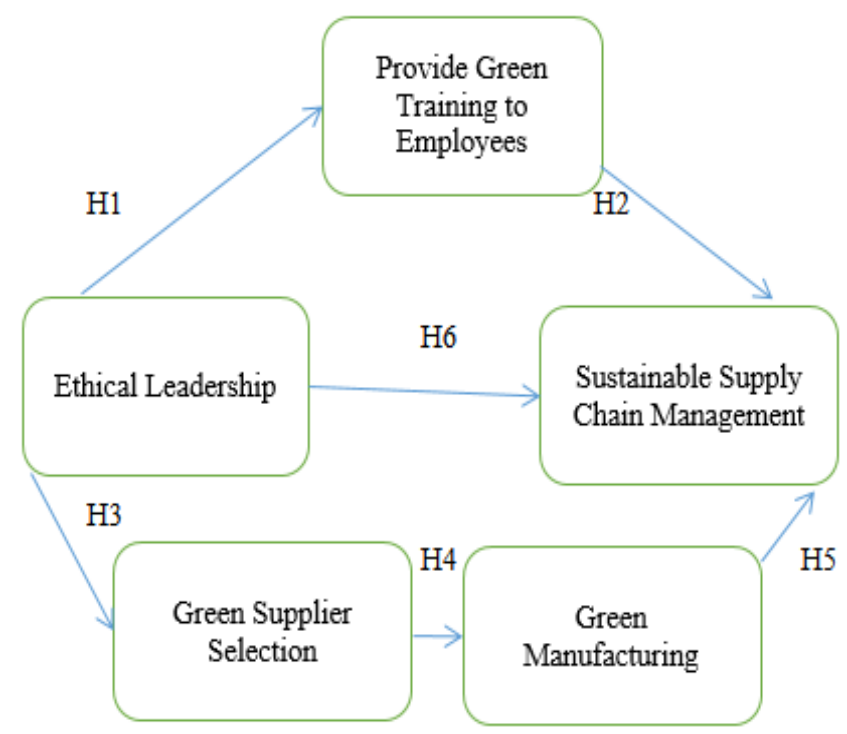

Fig. 1. Research model

\section{RESUlts AND Discussion}

For the measurement model, as shown in Table 2, the ratio of the minimum discrepancy (CMIM) to the degree of freedom (DF) for this model was $2.31(p<0.05)$ which is smaller than 3 as recommended by Byrne [15]. Other model fit indices include AGFI $=0.9 ; \mathrm{GFI}=0.92 ; \mathrm{NNFI} / \mathrm{TLI}=0.94 ; \mathrm{CFI}=0.96$; SRMR $=0.05$; and RMSEA $=0.06$ with insignificant PCLOSE value. All values exceeded the recommended criteria as described in Table 2. The results of measurement suggest that the CFA appears to show a good fit between the observed and unobserved variables [15]. The following part discussed SEM used in this study.

Table 3 displays the results of structural equation modeling. The results confirmed that the $\mathrm{H} 1, \mathrm{H} 2, \mathrm{H} 3, \mathrm{H} 5$, and $\mathrm{H} 6$ are supported the claim, while $\mathrm{H} 4$ is not supported the claim of our research, which has been presented in literature review and hypothesis formulation section.

The findings revealed that "ethical leader" has positive and significant relationship with green trainings to employees and $1 \%$ increase in ethical leadership will increase "green trainings provided to employees" by $0.213 \%$ on $1 \%$ confidence level. These results are also supported by Khan and Dong. [16] conducted an empirical study in the context of manufacturing firms of Pakistan and they concluded that ethical leadership improves the green practices in supply chain management. Khan et al. [6] highlighted that internal environmental management motivates employees to work towards sustainable supply chain, which not only improves firms' financial performance but also builds collaboration with different supply chain partners.
TABLE II. MEASURES OF THE MODEL FIT

\begin{tabular}{|c|c|c|c|c|c|}
\hline $\begin{array}{l}\text { Goodness-of-fit } \\
\text { measures }\end{array}$ & CMIN & DF & CMIN/DF & $p$ value & GFI \\
\hline $\begin{array}{l}\text { Recommended } \\
\text { value }\end{array}$ & & & $<3$ & $>0.05$ & $\geq 0.90$ \\
\hline $\begin{array}{l}\text { CFA measurement } \\
\text { model }\end{array}$ & 241.154 & 107 & 2.31 & 0 & 0.92 \\
\hline $\begin{array}{l}\text { SEM structural } \\
\text { model }\end{array}$ & 191.214 & 105 & 1.89 & 0 & 0.93 \\
\hline $\begin{array}{l}\text { Goodness-of-fit } \\
\text { measures } \\
\end{array}$ & TLI & AGFI & RMSEA & CFI & ECVI \\
\hline $\begin{array}{l}\text { Recommended } \\
\text { value }\end{array}$ & $\geq 0.90$ & $\geq 0.85$ & $\leq 0.08$ & $\geq 0.95$ & $\begin{array}{l}\text { Lowest } \\
\text { value }\end{array}$ \\
\hline $\begin{array}{l}\text { CFA measurement } \\
\text { model }\end{array}$ & 0.94 & 0.9 & 0.06 & 0.96 & 1.261 \\
\hline $\begin{array}{l}\text { SEM structural } \\
\text { model }\end{array}$ & 0.96 & 0.9 & 0.057 & 0.98 & 1.096 \\
\hline
\end{tabular}

The results show that "Green trainings provided to employees" is positively correlated with "Sustainable supply chain management" and $1 \%$ increase in green trainings will enhance sustainable supply chain management by $0.659 \%$. These results are also supported by Porter and Linde [17] and in this research sustainable supply chain is improved by green initiatives including green trainings and programs, green purchasing and reverse logistics.

\section{TABLE III. STRUCTURAL EQUATION MODEL RESULTS}

\begin{tabular}{|ccccc|}
\hline Hypothesis & $\begin{array}{c}\text { Standardized } \\
\text { Estimates }\end{array}$ & P value & Sign Observed & Remarks \\
\hline H1 EL > GTE & 0.213 & $0.000^{* * *}$ & Positive & Supported \\
H2 GTE > SSC & 0.659 & $0.001^{* *}$ & Positive & Supported \\
H3 EL > GSS & 0.416 & $0.000^{* * *}$ & Positive & Supported \\
H4 GSS > GM & 0.423 & 0.211 & Negative & Not Supported \\
H5 GM > SSC & 0.289 & $0.000^{* * *}$ & Positive & Supported \\
H6 EL > SSC & 0.210 & $0.000^{* * *}$ & Positive & Supported \\
\hline
\end{tabular}

Notes: EL =Ethical Leadership; GTE = Green trainings to employees; SSC = Sustainable supply chain; GSS = Green supplier selection; GM = Green manufacturing $* * * \mathrm{p}<0.001 ; * * \mathrm{p}<0.01$.

The findings show that green manufacturing is positively and significantly correlated with sustainable supply chain management on $1 \%$ confidence level. In simple words, $1 \%$ increase in "green manufacturing" practices will improve "sustainable supply chain" by $0.289 \%$, while the result is also supported by [11 and 12] in this result, green manufacturing reduces the air pollution and waste with better firms' environmental and operational performance. Green manufacturing helps companies to achieve superior financial performance [12]. On the other hand, the findings indicate that "Green supplier selection" 


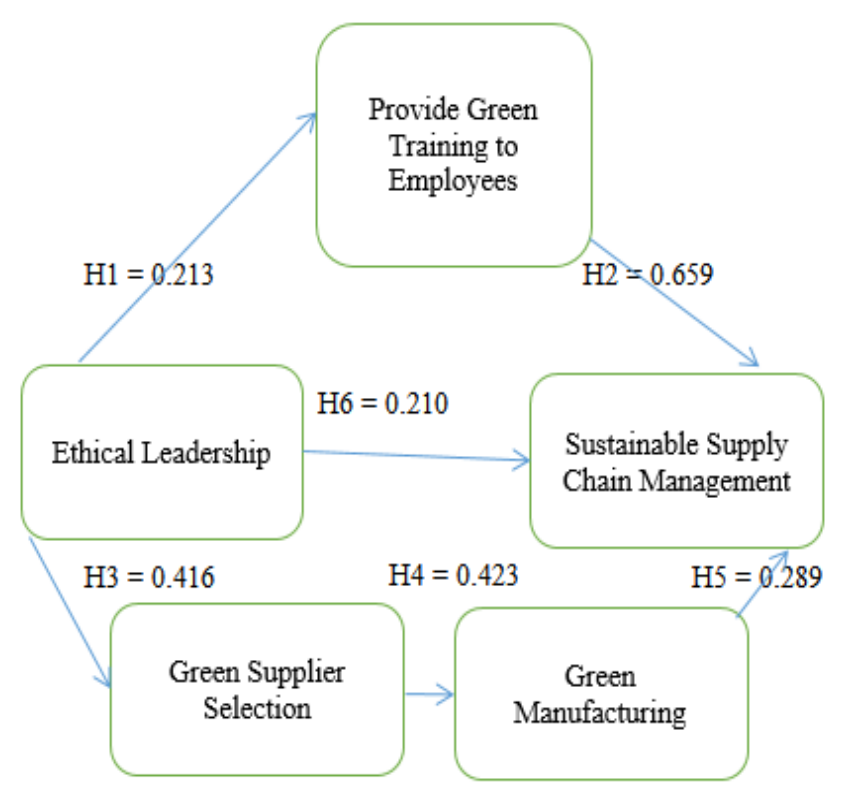

Fig. 2. Research model with Regression Coefficients

\section{Conclusion and Future Research}

This research examines the role and impact of ethical leadership, green trainings, green supplier selection and green manufacturing on sustainable supply chain. The findings revealed that ethical leadership plays a significant part in adoption of sustainable supply chain through different determinants including green trainings provided to employees, environmental friendly supplier selection and green manufacturing. Hence, it is recommended that firms' leadership should act ethically for successful implementation of green practices in business operations. This research was conducted in manufacturing firms in India, while future research may concentrate on comparative studies between manufacturing sector and other sectors in India. In addition, future study may also be conducted with other determinants of green practices including, green procurement, green distribution, recycling and remanufacturing techniques, green information systems and reverse logistics.

\section{REFERENCES}

[1] Khan, S.A.R., Dong, Q.L., Yu, Z, "Research on the measuring performance of green supply chain,” Intl. J. Eng. Res. Afr, Vol. 24,2016, pp. 172-180.

[2] Judge, W. Q., and T. J. Douglas, "Performance implications of incorporating natural environmental issues into the strategic planning process: An empirical assessment,” J. Mang. Std. Vol. 35, No. 2, 1998, pp. 241-262.

[3] Huiying, Z. F., and Fan, Y., "On the drivers and performance outcomes of green practices adoption: an emp irical study in Ch ina,” Ind. Mang. D. Sys. Vol. 116, No. 9, 2016, pp. 24-39.

[4] Khan, S.A.R., Zhang, Y., Anees, M., Golpîra, H., Lahmar, A., Dong, Q., "Green supply chain management, economic growth and environment: A GMM based evidence,” J. Cleaner. Prod. Vol. 185, 2018. pp. 588-599.

[5] Aldakhil, A.M., Nassani, A.A., Awan, U., Abro, M.M.Q., Zaman, K., "Determinants of green logistics in BRICS countries: An integrated supply chain model for green business,” J. Clean Prod. Vol. 195, 2018, pp. 861-868.

[6] Khan, S.A.R., Qianli, D., Songbo, W., Zaman, K., Zhang, Y., "Environmental logistics performance indicators affecting per capita income and sectoral growth: evidence from a panel of selected global ranked logistics countries,” Environ. Sci. Pollut. Res. Vol. 24(2), 2017, pp. 1518-1531.

[7] Luthra, S., Garg, D., Haleem, A., “The impacts of critical sucess factors for implementing green supply chain management towards sustainability an empirical investigation of Indian automobile industry,” J. Clean. Prod. Vol. 121, 2016, pp. 142-158.

[8] Jacobs, B.W., Singhal, V.R., Subramanian, R., “An empirical investigation of environmental performance and the market value of the firm,” J. Opr Mgmt, Vol. 28, 2010, pp. 430-441

[9] Mitra, S., \& Datta, P.P., “Adoption of green supply chain management practices and their impact on performance: An exploratory study of Indian manufacturing firms,” Intl. J. Pro. Res, Vol. 52, 2014, pp. 2085 2107.

[10] Bansal, P., "Evolving sustainabily: A longitudinal study of corporate sustainable development,” Stra. Mgmt. J, Vol. 26, 2005, pp. 197-218.

[11] Prajogo, D., Chowdhury, M., Yeung, A. C., \& Cheng, T.C.E., “The relationship between supplier management and firm's operational performance: a multi-dimensional perspective,” Intl. J. Prod. Eco, Vol. 136, 2012, pp. 123-130.

[12] Christmann, P., “Effects of best practices of environmental management on cost advantage: The role of complementary assets,”Acad. Mgmt. J, Vol. 43, 2000, pp. 663-680.

[13] Banerjee, S.B., "Managerial perceptions of corporate environmentalism: Interpretations from industry and strategic implications for organizations,” J. Mgmt Stud. Vol. 38, 2001, pp. 489-513.

[14] Hart, S.L., “A natural-resource-based view of the firm,” Acad. Mgmt Rev, Vol. 20, No. 4, 1995, pp. 986-1014.

[15] Byrne, B.M., "Structural equation modeling with AMOS: Basic concepts, applications, and programming. New York: Routledge.

[16] Khan, S.A.R., and Dong, Q., "Impfact of green supply chain management practices on firms' performance: An empirical study from the perspective of Pakistan,” Environ. Sci. Pollut. Res, Vol. 24, No. 20, 2017, pp. 16829-16844.

[17] Porter, M., and Linde, C.V.D., "Green and competitive: Ending the stalemate,” Harvard Business Review, Vol. 73, 1995, pp. 120-124. 